\title{
A Method for Preparing Bead Shaped Immobilized Enzyme
}

\author{
Koji KaWASHIMA and Keiji UMEDA \\ National Food Research Institute, Ministry of Agriculture and Forestry \\ Received December 15, 1975
}

\begin{abstract}
Monomer solution containing enzyme was frozen to a small bead shape by cool solvent and polymerized by Co-60 gamma ray with a dose of $125 \sim 850 \mathrm{Krad}$.

Thus, bead shaped immobilized enzymes with various diameters $(0.02 \sim 15 \mathrm{~mm})$ were obtained.

The bead had spongy structure and large surface area. Consequently, even large sized bead shaped immobilized enzyme showed high enzymic activity.

Retained activity of bead shaped immobilized invertase was $16 \sim 73 \%$ depending on bead size.

Bead shaped lipase ( $1 \mathrm{~mm}$ diameter) showed $13.5 \sim 42.5 \%$ of retained activity depending on monomer combinations.
\end{abstract}

Many methods have been reported to immobilize enzymes ${ }^{1)}$ and the industrial application of immobilized acylase is known. ${ }^{2}$ To immobilized enzymes, some workers have used irregular carriers such as cellulose derivatives, starch derivatives, acrylamide gel, and sephadex.

In the practical application of immobilized enzyme, it is desirable to have a regular form as well as high retained activity and high mechanical strength. Enzyme column will be one of the most important application of immobilized enzyme and to realize enzyme column, bead shaped immobilized enzyme will be essential. Further, bead shaped immobilized enzyme will be favoured as a model system for the kinetic study of immobilized enzyme reaction.

Some publications described bead shaped immobilized enzyme using preformed bead shaped carriers such as glass bead ${ }^{3,4)}$ polystyrene bead, ${ }^{5)}$ polyacrylamide gel derivative bead, ${ }^{6,7)}$ and so on. However, these carriers are sometimes too expensive and weak. As for the bead size, it is non-selective and usually extremely small in order to increase the surface

$\uparrow$ Studies on the Immobilized Enzymes by Radiopolymerization. Part III.

A part of this work was presented at the Annual Meeting of the Japanese Society of Starch Science held on June 24 th, 1975 in Tokyo. area. Further, enzymes are easily inactivated by the immobilization process.

A bead-polymerization technique of acrylic monomer is known. ${ }^{8,9)}$ However, in this technique, chemical polymerization is conducted for a long time in anaerobic conditions and enzyme inactivation due to the catalyzer is inevitable.

Authors have reported a method to immobilize enzyme by aerobic radiocopolymerization of monomers at the frozen temperature. ${ }^{10,11)}$ In this method, various kinds of synthetic monomers can be used besides acrylamide and corresponding polymers with various characteristics were obtained.

In the present paper, as an improvement of procedures already in use, ${ }^{10,11)}$ a new technique to prepare bead shaped immobilized enzyme (yeast invertase and mold lipase) is described. Any enzymes and microorganisms can be immobilized in a bead shape in the mild condition without carriers. Bead size can be controlled from about $20 \mu$ to $15 \mathrm{~mm}$ and a bead as small as microcapsule is obtainable.

\section{METHODS AND MATERIALS}

Enzyme. Invertase was purchased from Seikagaku Kogyo Co. Ltd. (pure grade, C. Utilis invertase). Lipase was purchased from Tanabe Seiyaku Co. Ltd. (Rhizopus delemer lipase). 
Synthetic monomer. The following monomers were subjected to radiation copolymerization in the presence of enzymes.

a) $\mathrm{AA}$ ( $23 \%$ aqueous solution of acrylamide containing $1.3 \%$ of $\mathrm{NN}^{\prime}$ methylene bis acrylamide)

b) $\mathrm{ANa}(30 \%$ aqueous solution of sodium acrylate)

c) $\mathrm{ACa}(30 \%$ aqueous solution of calcium acrylate)

d) $\mathrm{P}(20 \%$ aqueous solution of 1-vinyl-2-pyrrolidone)

e) HEMA ( $30 \%$ aqueous solution of hydroxyethylmethacrylate)

f) DS (divinyl sulfone)

Gamma irradiation. Gamma cell 220 (Canada AEC; Co-60, $7800 \mathrm{Ci}$ ) was applied in the irradiation process. Dose rate was $650 \sim 750 \mathrm{Krad} / \mathrm{hr}$. Irradiation was performed aerobically at about $-80^{\circ} \mathrm{C}$.

Immobilization of invertase in bead shape. Synthetic monomers and distilled water containing invertase $(1 \sim 2 \mathrm{mg} / \mathrm{ml})$ were combined in the following ratios; AA: $\mathrm{ANa}: \mathrm{ACa}$ : dist. water $=1: 1: 2: 1$ (ml). The mixture is called enzyme-monomer solution. $\mathrm{N}$-Hexane, $100 \mathrm{ml}$, was placed into a $200 \mathrm{ml}$ flask and cooled in dry ice acetone. The enzyme-monomer solution was injected into the cooled $n$-hexane. The solution was immediately frozen and white small beads sank to the bottom of the flask. The bead size can be controlled by the spead of injection, or by the viscosity of the fluid into which enzyme-monomer solution is injected. The frozen beads were subjected to gamma irradiation under aerobic conditions untill radiocopolymerization was fully achieved (125 $850 \mathrm{Krad})$. After irradiation, the $n$-hexane was discarded and the bead shaped polymer produced was thawed gradually in ice water. Finally, bead immobilized invertase $(0.3 \sim 5 \mathrm{~mm}$ diameter $)$ was obtained.

If a large bead is preferred, the enzyme monomer solution is added drop by drop to cool vegetable oil such as soybean oil and then quickly frozen. After irradiation, thawing and washing with detergent and water, large beads $(5 \sim 15 \mathrm{~mm}$ diameter) are obtained. When an extremely small bead is desired, the enzymemonomer solution $(0.2 \mathrm{ml})$ is mixed with toluene or vegetable oil $(10 \mathrm{ml})$ and surface activating agent, if necessary, $(1 \sim 2$ drops of tween 20$)$ and vigorously stirred. Then, the emulsion is quickly frozen in the coolant (dry ice acetone) and subjected to gamma irradiation. After thawing and filtration, small bead shaped immobilized enzyme $(0.02 \sim 0.1 \mathrm{~mm}$ diameter) results. Thus, the beads as small as microcapsule are obtained.

Immobilization of lipase in bead shape. Rhizopus lipase $(1.0 \mathrm{~g})$ was absorbed in SE Sephadex $(0.1 \mathrm{~g})$ dispersed in water $(20 \mathrm{ml})$. This solution is referred to as $\mathrm{L}$ hereafter. The process is for the purpose of enzyme refining and also would be effective to protect the leakage of entrapped enzyme. The synthetic monomers and lipase solution $\mathrm{L}$ were combined as in Table I. Enzyme-monomer solutions prepared as in Table I were injected into cooled petroleum ether and

$$
\begin{gathered}
\text { TABle I. COMbination of Monomers } \\
\text { AND ENZyME FOR the Radiocopoly- } \\
\text { MERIZATION }
\end{gathered}
$$

See the text for the abbreviation denotation

\begin{tabular}{cccccccc}
\hline No. & L & AA & ANa & $\begin{array}{c}\text { ACa } \\
(\mathrm{ml})\end{array}$ & HEMA & P & D.S \\
\hline 1 & 1 & 2 & & 2 & & & \\
2 & 1 & 1 & 1 & 2 & & & \\
3 & 1 & & 2 & 2 & & & 0.1 \\
4 & 1 & 1 & 1 & 1 & & 2 & \\
5 & 1 & & & 3 & & 1 & 0.1 \\
6 & 1 & & 1 & 1 & 2 & & 0.1 \\
\hline
\end{tabular}

frozen into bead shapes. After gamma irradiation, cooled petroleum ether was exchanged with ice water and polymer was gradually thawed. Thus, bead shaped immobilized lipase $(0.5 \sim 1.5 \mathrm{~mm}$ diameter $)$ was obtained.

\section{Activity assay}

Invertase. The bead shaped invertase obtained was wased with water thoroughly and $100 \sim 500 \mathrm{mg}$ of it was weighed, mixed with $8 \mathrm{ml}$ dist. water, $1 \mathrm{ml}$ of $0.2 \mathrm{~N}$ citrate phosphate buffer $(\mathrm{pH} 4.0$ ) and $1 \mathrm{ml}$ of $10 \%$ sucrose. Enzyme reaction was conducted at $40^{\circ} \mathrm{C}$ for $20 \mathrm{~min}$ and the glucose produced was assayed by the glucose oxidase method or by the WillstatterShudel method, titrating with $\mathrm{N} / 100 \quad \mathrm{Na}_{2} \mathrm{~S}_{2} \mathrm{O}_{3}$.

For comparison purposes, native enzyme $(5 \sim 40 \mu \mathrm{g})$ was similarly treated at $\mathrm{pH} 4.5$.

Lipase. Native lipase $(1 \mathrm{ml})$ or immobilized bead shaped lipase $(0.1 \sim 1.0 \mathrm{~g})$ was mixed with olive oil $(2.4 \mathrm{ml}), \mathrm{M} / 10 \mathrm{CaCl}_{2} \cdot 2 \mathrm{H}_{2} \mathrm{O}(1 \mathrm{ml})$ and $\mathrm{M} / 20$ acetate buffer $(\mathrm{pH} 5.6,9 \mathrm{ml})$. The above solution was stirred at $600 \mathrm{rpm}$ for $30 \mathrm{~min}$ at $30^{\circ} \mathrm{C}$. The reaction was stopped adding $40 \mathrm{ml}$ of methanol and the produced fatty acid content was titrated with $\mathrm{N} / 20 \mathrm{NaOH}$ to $\mathrm{pH}$ 9.0. Enzyme activity was based on the volume of titrated $\mathrm{NaOH}$ solution.

\section{RESULT AND DISCUSSION}

\section{Effect of fluid into which enzyme-monomer solution was injected}

Before radiocopolymerization, enzymemonomer solution is frozen to bead shape in cooled fluid which does not inactivate enzyme activity. Bead shaped immobilized invertase 
was prepared using various kinds of cooled fluids. Enzyme-monomer solution, $5 \mathrm{ml}$, (AA: ANa: ACa: invertase $(2 \mathrm{mg} / \mathrm{ml})=1: 1: 2$ : 1) was injected into each fluid and $1 / 100$ of total product was subjected to activity assay.

Results are shown in Table II. As a freezing fluid, nonpolar solvents, such as $n$-hexane or

Table II. Effect of Freezing Flutd on tHE BEAD Formation AND ACTIVITY OF IMMOBILIZED ENZYME

\begin{tabular}{lcc}
\hline \multicolumn{1}{c}{ Fluid } & $\begin{array}{c}\text { Bead } \\
\text { formation }\end{array}$ & Activity $^{d 3}$ \\
\hline$n$-Hexane & $++a)$ & 100 \\
Petroleum ether & ++ & 100 \\
Toluen & ++ & 100 \\
Xylene & ++ & 98 \\
Ethyl ether & ++ & 94 \\
Methylethylketone & ++ & 86 \\
Butanol & ++ & 80 \\
Ethyl acetate & ++ & 80 \\
Soybean oil & ++ & 75 \\
\hline Amylalcohol & $+b)$ & 95 \\
\hline Benzene & + & 95 \\
Trichloroethylene & + & 90 \\
Carbon tetrachloride & + & 95 \\
\hline Methanol & $-\infty$ & 0 \\
Ethanol & - & 0 \\
Propanol & - & 0 \\
Acetone & - & 0 \\
\hline
\end{tabular}

a) $t+$ bead formed.

b) + massive gel formed.

c) no polymer formed.

d) Activity of invertase immobilized in $n$-hexane was assumed as 100 .

toluene was desirable. In these solvents regular bead shaped polymer $(0.7 \sim 1.2 \mathrm{~mm}$ diameter) was obtained. Soybean oil produced rather big beads $(2 \sim 3 \mathrm{~mm}$ diameter) which resulted in lower activity. In polar solvents such as methanol and acetone, enzyme-monomer solution easily mixed with solvent and no polymerization occured.

Frozen beads formed in amylalcohol combined with each other at the bottom of flask and massive polymer was produced after gamma irradiation. Other solvents such as benzene, carbontetra-chloride and chloroform were not suitable as freezing fluid because they have higher gravity than monomer solution.

\section{Effect of thawing process}

In the present method, after gamma irradiation in the frozen state, the produced polymer was thawed and bead shaped immobilized enzyme was obtained. The process of thawing influences the retained activity of immobilized enzyme. Five $\mathrm{ml}$ of invertase monomer solution (AA: ANa: ACa: enzyme sol. $(2 \mathrm{mg} /$ $\mathrm{ml})=1: 1: 2: 1)$ was injected into cooled $n$ hexane and sujected to gamma irradiation $(120.2 \mathrm{Krad})$. After irradiation a) frozen polymer in cooled $n$-hexane was left in the room and thawed gradually, b) cooled $n$-hexane was discarded and ice water was added to frozen bead shaped polymer and thawed gradually, c) cooled $n$-hexane was discarded and cool citrate-phosphate buffer $(\mathrm{pH} 4.0 \mathrm{M} / 50)$ was added to frozen bead shaped polymer and thawed gradually, d) cooled $n$-hexane was discarded and immediately the frozen polymer was washed with hot water $\left(42^{\circ} \mathrm{C}\right)$. Bead shaped immobilized invertase were thus thawed washed with water, 1/100 of the total products were weighed and subjected to activity assay. Relative activities of bead shaped immobilized invertases which were thawed according to a), b), c) and d) were 83.7, 100.0, 100.0 and 92.2 respectively. Results show that it is better to discard cooled fluid immediately after irradiation. The rapid increase of temperature up to $42^{\circ} \mathrm{C}$ had no significant on the activity of immobilized invertase.

\section{Activity of bead shaped immobilized invertase}

Five $\mathrm{ml}$ of enzyme-monomer solution containing $2.0 \mathrm{mg}$ of invertase was injected gently into cooled petroleum ether and immediately frozen. Then it was radiocopolymerized with a dose of 752 Krad. After thawing and washing with water bead shaped immobilized enzyme $(0.5 \sim 1.0 \mathrm{~mm}$ diameter $)$ was obtained.

A part of it $(1 / 200 \sim 4 / 200)$ was weighed and subjected to activity assay at $40^{\circ} \mathrm{C}$. Reaction curves are shown in Fig. 1 and glucose production by various amounts of immobilized 


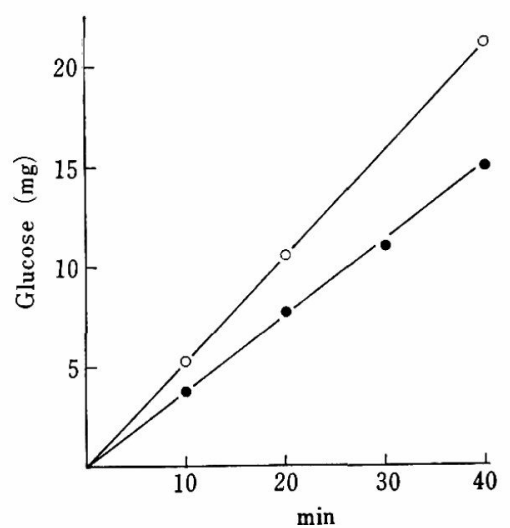

FIG. 1. Reaction Curves of Invertase.

Reaction mixture for immobilized invertase; $1 \mathrm{ml}$ $10 \%$ sucrose, $1 \mathrm{ml} 0.2 \mathrm{~N}$ Citrate phosphate buffer (pH 4.0), $8 \mathrm{ml}$ dist. water and bead polymer entrapping $10 \mu \mathrm{g}$ invertase.

For native invertase; $1 \mathrm{ml} 10 \%$ sucrose, $1 \mathrm{ml} 0.2 \mathrm{~N}$ buffer ( $\mathrm{pH} 4.5$ ), dist, water $7 \mathrm{ml}$, and $1 \mathrm{ml}$ enzyme $(10 \mu \mathrm{g})$.

Reaction; $40^{\circ} \mathrm{C}$

$\mathrm{O}-\mathrm{O}$, native; $-\mathbf{O}$, immobilized.

invertase are shown in Fig. 2.

Bead shaped immobilized enzymes with a diameter of $0.2 \sim 12 \mathrm{~mm}$ were prepared by injecting $5 \mathrm{ml}$ of enzyme-monomer solution containing $2 \mathrm{mg}$ of invertase into cooled petroleum ether, toluene and soybean oil according to the method described here. Bead shaped

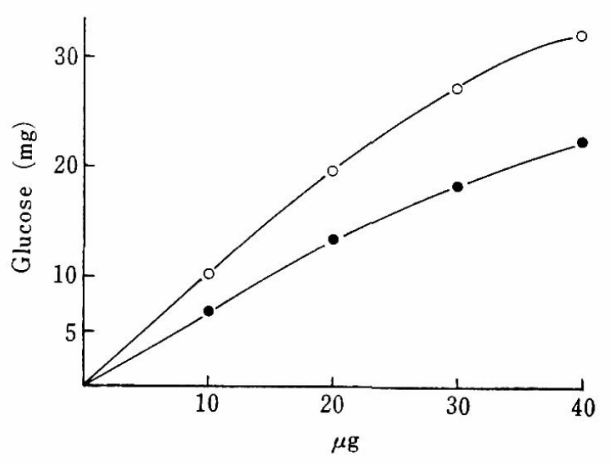

Fig. 2. Production of Glucose by Invertase at Various Enzyme Concentration.

Reaction mixture for immobilized invertase; $3 \mathrm{ml}$ $10 \%$ sucrose $2 \mathrm{ml}$ citrate phosphate buffer (pH 4.0), $5 \mathrm{ml}$ dist. water, bead polymer entrapping $10 \sim 40 \mu \mathrm{g}$ invertase.

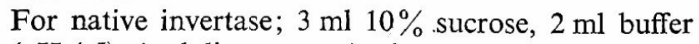
(pH 4.5), $4 \mathrm{ml}$ dist. water, $1 \mathrm{ml}$ enzyme sol. containing $10 \sim 40 \mu \mathrm{g}$ invertase reaction; $40^{\circ} \mathrm{C}, 20 \mathrm{~min}$.

$\mathrm{O}-\mathrm{O}$, native; - , immobilized.

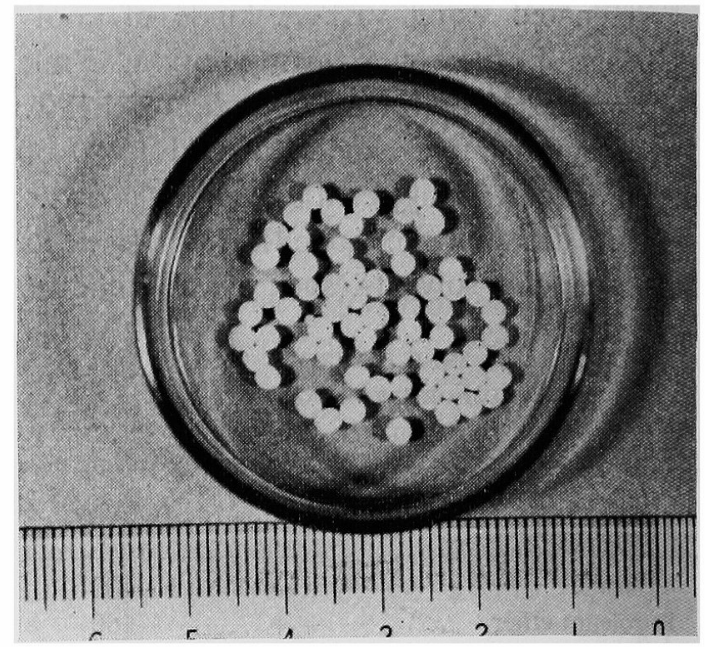

Fig. 3. Bead Shaped Immobilized Invertase.

immobilized enzyme obtained is shown in Fig. 3.

A part of each immobilized preparations (100 $\sim 500 \mathrm{mg}$ ) was weighed and submitted to activity assay and compared to the activity of corresponding native invertase. Enzyme was assumed to be completely entrapped in the polymer and the retained activity was calculat-

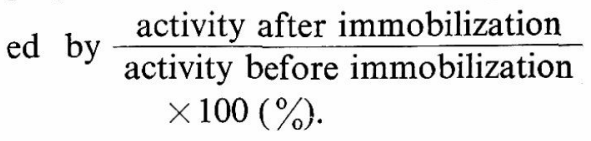

Relation between bead size and retained activity

Figure 4 shows that the smaller bead has the higher activity. This might be explained by the effect of surface area of bead. However, the change of retained activity did not coincide with that of surface area, especially when bead size is smaller than $1 \mathrm{~mm}$. There were no significant in retained activity.

The bead shaped polymer prepared by the present method has a spongy structure. Figure 5 shows the electron microscopic view of bead surface prepared by the radiopolymerization of $16 \%$ pyrrolidone solution containing $1.6 \% \mathrm{~N}, \mathrm{~N}^{\prime}$ methylene-bis-acrylamide. (JEOL-50A, Magnification $\times 1.000$, Critical Point Drying Method.) Substrate will penetrate into the inside of bead along the small canals and the enzyme reaction will occur not only on the surface of bead itself but also within 


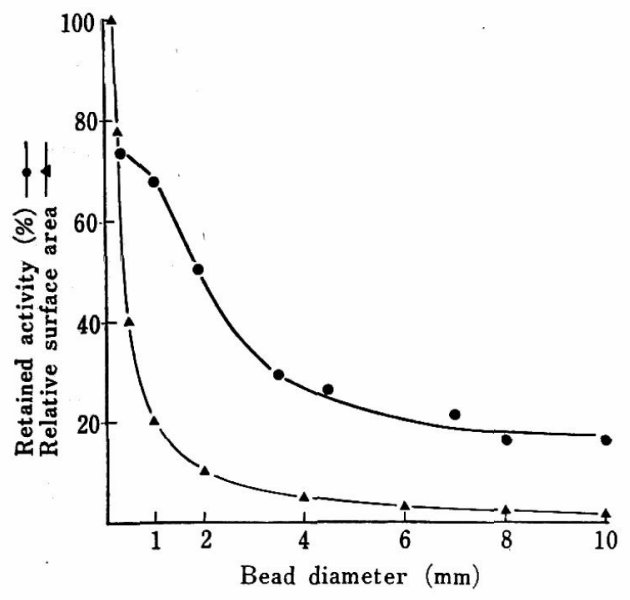

FIG. 4. Effect of Bead Size on the Retained Activities of Bead Shaped Immobilized Invertase and Surface Area.

$-\boldsymbol{-}$, retained activity; $\boldsymbol{\Delta}-\boldsymbol{\Delta}$, relative surface area. Beads were prepared from enzyme monomer solution containing $0.4 \mathrm{mg}$ of invertase per $\mathrm{ml}$.

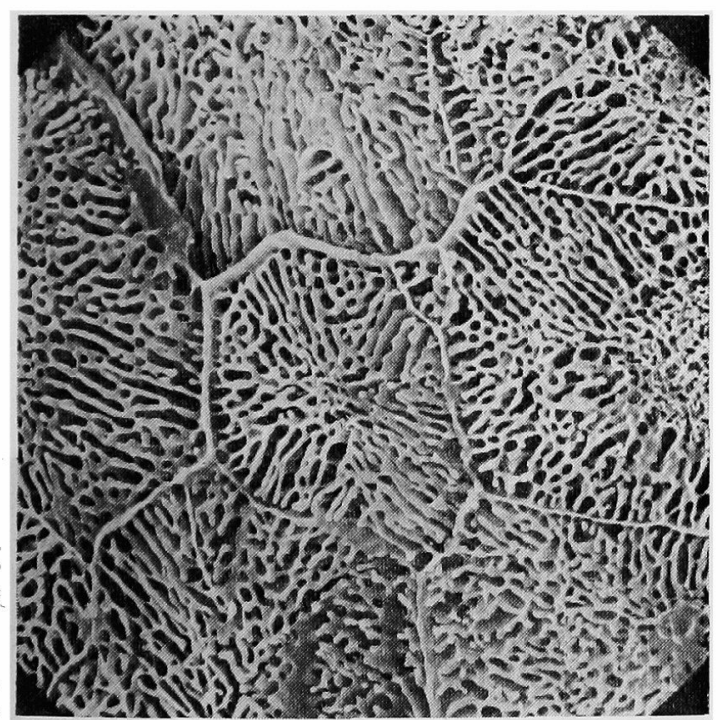

FIG. 5. Scanning Electron Microscopic View of Bead Surface. $(\times 1.000)$

the bead. The small canals are considered to be the area where ice was formed when enzymemonomer solution was frozen. Therefore, the retained activity of immobilized invertase did not simply correlate to the bead size. The retained activity of immobilized bead shaped invertase was about $16 \sim 73 \%$ depending on bead size.
Effect of enzyme concentration on the retained activity of immobilized bead shaped invertase. Bead shaped immobilized enzymes with a diameter of about $1 \mathrm{~mm}$ were prepered. Five $\mathrm{ml}$ of enzyme-monomer solution containing $0.5 \sim 50 \mathrm{mg}$ of invertase were subjected to irradiation.

After thawing and washing thoroughly with water, $1 / 50 \sim 1 / 250$ of total products were weighed and their enzymic activity were assayed. Native invertase $(5 \sim 80 \mu \mathrm{g})$ was similarly reacted and retained activities of each immobilized enzyme preparation were determined. A decrease in activity was accompanied by an increase in enzyme concentration (Fig. 6). Even more than $90 \%$ of retained

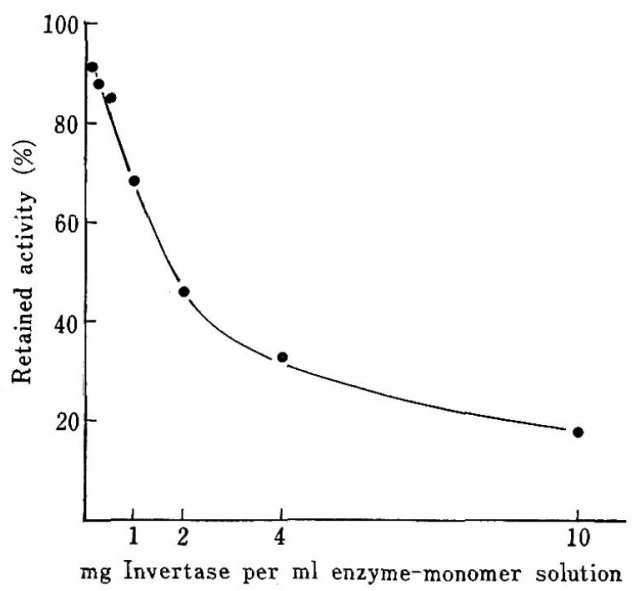

FIG. 6. Relation between Enzyme Concentration and Retained Activities of Bead Shaped Immobilized Invertase.

Bead shaped immobilized invertase $(0.5 \sim 1.0 \mathrm{~mm}$ diameter) were prepared from $5 \mathrm{ml}$ of enzyme monomer solution and $1 / 50$ of each preparation was submitted to reaction.

activity was obtained at low enzyme concentration. The bead size is about $1 \mathrm{~mm}$ in this case and a little higher retained activity would be expected when smaller beads are prepared.

\section{Activity of bead shaped immobilized lipase}

As can be seen in Table I, six varieties of bead shaped immobilized lipase were prepared. The bead size of every preparation is about $1 \mathrm{~mm}$ in diameter. The retained activity was 
dependent upon the monomer composition: $36.6 \%$ (No. 1), $39.8 \%$ (No. 2), $14.5 \%$ (No. 3), $42.5 \%$ (No. 4), $4.8 \%$ (No. 5), and $13.5 \%$ (No. $6)$ were determined respectively. The reaction curves of native lipase are shown in Fig. 7.

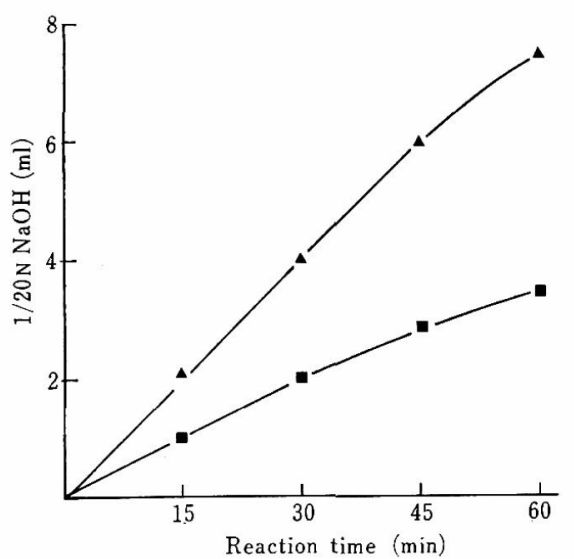

FIG. 7. Reaction Curves of Lipase.

Native lipase ( $-\boldsymbol{\square}, 0.67 \mathrm{mg} ; \boldsymbol{\Delta}-\mathbf{\Delta}, 1.34 \mathrm{mg}$ ) was subjected to the reaction which was conducted as described in the text. If $1 \mathrm{ml}$ of $\mathrm{NaOH}(n / 20)$ was consumed in the titration after reaction ( $30 \mathrm{~min}$ ), the enzyme activity was defined as 5 units. Immobilized enzyme preparation was weighed so as to have 5 to 40 units and subjected to the reaction.

Immobilization process itself would not seriously decrease the enzymic activity if any. Because enzyme are generally highly resistant to ionising irradiation, especially at low tem- perature. Further, the monomers used were known not to inactivate enzymic activity. The structure of polymer would be different greatly depending on used monomer, especially on crosslinking agent.

The immobilized enzyme preparations No. 1,2 , and 4 contained bisacrylamide as a crosslinking agent and showed higer retained activities while the preparations No. 3, 5, and 6 contained divinylsulfone as a crosslinking agent showed lower activities. The amount of entrapped enzyme protein was not determined but it would be changed depending on the polymer structure and would reflect the retained activity of immobilized enzyme preparations.

\section{Preparation of various shaped immobilized enzyme}

The method described above has the advantage of simplicity for the preparation of bead shaped polymer entrapping enzymes. By freezing the enzyme-monomer solution before irradiation polymerization immobilized enzymes can be prepared in various forms such as membrane, tube, bag besides bead itself. Additionally, a polymer can be obtained as the enzyme-monomer solution was frozen in the cast.

As one practical application, immobilized enzyme will be utilized in an auto-analysis
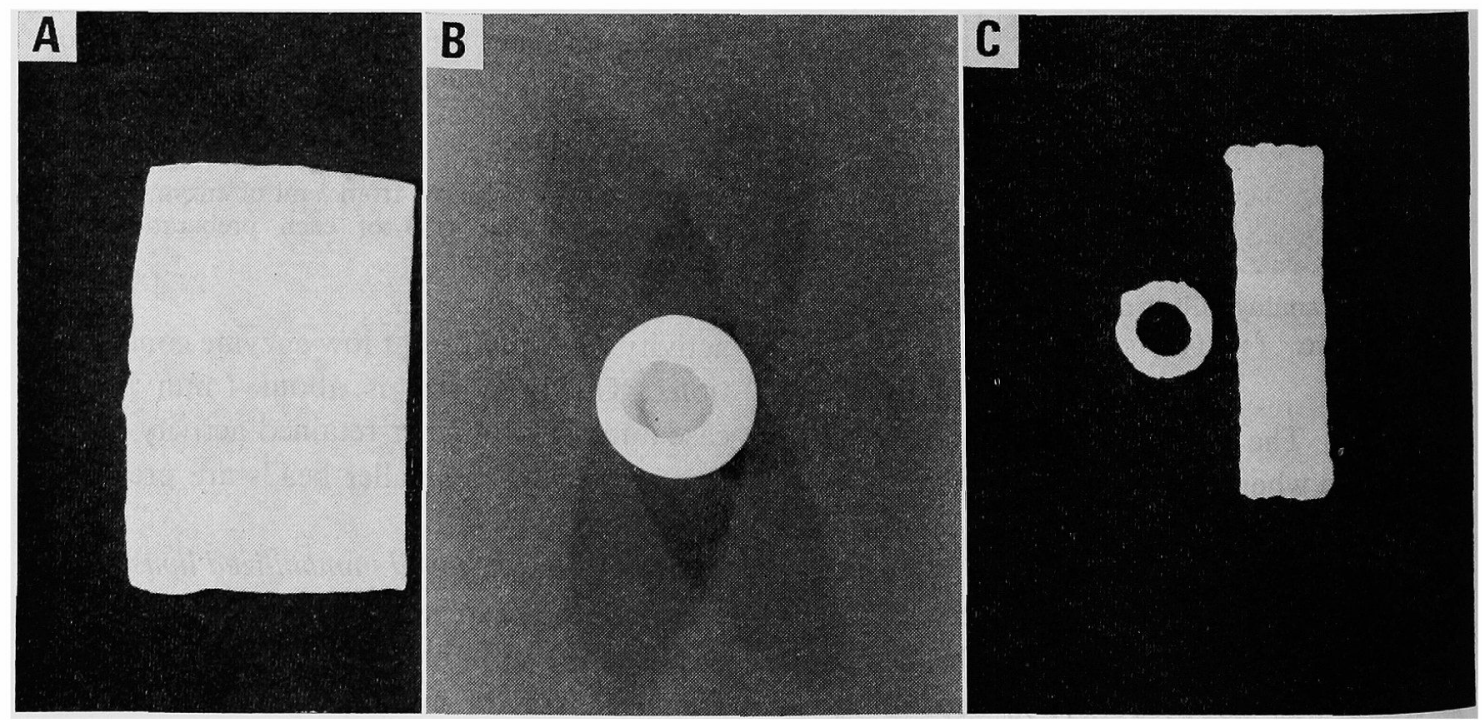

FIG. 8. Membrane (A), Bag (B), and Tube (C) Type Immobilized Invertase. 
instrunment system. ${ }^{12,13}$. For instance, bag shaped immobilized enzyme will be simply prepared by this method and will be attached to the head of sensors. Furthermore since it has spongy structure, this property will favorably influence the function of it. Membrane, bag and tube shaped polymer are shown in Fig. 8.

Acknowledgement. The authors are grateful to Dr. Kyoko Saio for the operation of Scanning Electron Microscope and Dr. Tomotaro Sato for his suggestions throughout the course of this invention.

\section{REFERENCES}

1) O. R. Zaborsky, "Immobilized Enzyme," CRC Press, Cleveland, Ohio, 1973.

2) I. Chibata, Kagaku Kogyo, 17, 65 (1973).
3) R. O. Mason and H.H. Weetall, Biotecnol, Bioeng., 16, 637 (1972).

4) A. R. Neurath and H. H. Weetall, FEBS lett., 8, 253 (1970).

5) H. Fillipusson and W. E. Hornby, Biochem. J., 120, 215 (1970).

6) K. Inman and H. M. Dintzis, Biochemistry, 8, 4074 (1969).

7) P. D. Weston and S. Avrameas, Biochemi. and Biophys. Res. Commun., 45, 1574 (1971).

8) H. Nilsson, R. Mosbach and K. Mosbach, Biochim. Biophys. Acta, 268, 253 (1972).

9) A. Johansson, J. Lundberg, B. Mattiasson and $\mathrm{K}$. Mosbach, ibid., 304, 217 (1973).

10) K. Kawashima and K. Umeda, Biotechnol. Bioeng., 16, 609 (1974).

11) K. Kawashima and K. Umeda, ibid., 17, 599 (1975).

12) L. Trauberman, Food Eng., 47, 58 (1975).

13) G. A. Rechnitz, $C \& E N$, 53, 29 (1975). 